\title{
Determinants of Non-Resident Deposits in Commercial Banks: Empirical Evidence from Lebanon
}

\author{
Olga Kanj $^{1}$ \& Rim El Khoury ${ }^{1}$ \\ ${ }^{1}$ Department of Accounting, Economics and Finance, Notre Dame University, Lebanon \\ Correspondence: Olga Kanj, Department of Accounting, Economics and Finance, Notre Dame University, Zouk \\ Mosbeh, Lebanon. Tel: 961-3-012-964. E-mail: omkanj@ndu.edu.lb
}

Received: September 30, 2013

Accepted: October 18, 2013

Online Published: November 26, 2013

doi:10.5539/ijef.v5n12p135

URL: http://dx.doi.org/10.5539/ijef.v5n12p135

\begin{abstract}
Given the fact that the government debt is financed by commercial banks in Lebanon, there is a need to uncover and study the determinants of commercial bank deposits. This paper investigates empirically the main determinants of non-residents deposits in Lebanese commercial banks using monthly time series data covering January 2002 to January 2013 (131 observations). The necessary tests were performed so that the ordinary least square regression can be safely applied. The estimated model had non-resident deposits as the dependent variables, and the explanatory variables as internal factors, external variables, and bank specific variables. The dependent variable was measured in three ways: in the local currency, in foreign currency, and total non-resident deposits. The results show that non-residents' deposits are shaped differently between domestic and foreign currency. For instance, bank assets, interest rates, and some adverse political situations affect non-resident deposits in all its measures. However, while total non-resident deposits and foreign non-residents deposits are roughly affected by the same factors, local resident deposits seem to be affected by other factors; this fact is attributed to the fact that local currency deposits account for a small percentage of total non-resident deposits. Based on the results, several policy implications were drawn that aim at increasing non-resident deposits. First, the stability of macroeconomic system should be maintained. Second, the government should maintain healthy rate differentials to support the deposit growth. Lastly, Lebanese banks should search for internalization to diversify their losses.
\end{abstract}

Keywords: banks, non-resident deposits, Lebanon

\section{Introduction}

Commercial banks, being the main players and the most active sector, have traditionally acted as a backbone of the Lebanese economy. They had played an essential and peculiar role in the progress of the Lebanese economy through supporting the private sector, backing the structural current account deficit, and financing the high government debt by attracting customers' deposits and investing them in sovereign securities.

Starting in 1992, the Lebanese banking sector has experienced a growth in its activities that exceeded the growth in domestic GDP (Hakim \& Neaime, 2001). Its performance is dependent on the influx of deposits with the latter constituting $83.5 \%$ of total assets at the end of November 2012. At the end of year 2011, ratios of banks' assets/GDP and banks' deposits/GDP reached around 359.58\% and 296\% respectively, highlighting the important size of the banking sector relative to that of the local economy (Byblos Bank, report \# 295).

Due to the high government debt financed by domestic commercial banks in Lebanon, their continued funding, from resident and non-resident deposits is of supreme importance to the financial system and to the economy. Non-resident deposits (NRD) are growing, having risen from only $4.93 \%$ in October 1983 to around $19.35 \%$ at the end of January 2013.

Despite the growth of NRD and the significance of deposits in Lebanese banks, little research has been done on analyzing the determinants of those deposits. Up to our knowledge, only Finger and Hesse (2009) studied the determinants of deposits in Lebanese commercial banks. However, they use total deposits as the dependent variable. This paper makes a number of distinct contributions that differentiate from Finger and Hesse's study. First, non-resident depositors can deposit their money in any country, and therefore, they might be affected by different factors than those affecting resident depositors. Therefore, this paper will use non-resident deposits as 
the dependent variable instead of total deposits. Second, non-resident deposits are further divided into local currency and foreign currency to investigate whether factors affecting non-resident deposits depend on the currency of the deposits. Third, the study adds important variables not previously considered that might determine non-resident deposits. Fourth, the study uses monthly instead of quarterly observations, which might provide better insights. Our study fills the gap by analyzing the determinants of non-resident deposits in a simple ordinary least square (OLS) framework.

\subsection{Overview of the Lebanese Banking System}

The financial sector in Lebanon, and specifically banks, had a major role throughout the cycles of the Lebanese economy. As mentioned by Dibeh (2005) and Finger and Hesse (2009), Lebanese economy's major players are the government and the financial system. Commercial banks were the major lender to the government since 1990s and the high fiscal deficits "was often counterbalanced by loans granted by the Lebanese Central Bank" (Naïmy, 2004).

Elthony (2003) indicates that credit to private sector in Lebanon is about 50 to 60 percent; this is due to the impact of crowding out of the private sector by the public sector despite the well-developed banking sector and the liberalization of credit policies. Banks financed the government both in local and foreign currencies. This special relationship between the banks and the state mediated by the central bank was instrumental in the prevention of a state default or currency crisis (Dibeh, 2005). Banks reconstituted their deposit base, since the government showed continuous demand for bank assets to finance the large deficits (Finger \& Hesse, 2009).

Measuring the banking activity growth by total assets, the sector grew by $8 \%$ in 2012 , as compared to a growth rate of $9 \%$ in 2011 and $11.9 \%$ in 2010 (Figure 1). Activity growth of Lebanese banking sector remained mainly driven by deposits mainly from the private sector. The deposits increased by $8 \%$ from end 2011 despite internal political instability and regional turmoil, such an increase in deposits is deemed sufficient to finance the economy as it exceeds the threshold of $5 \%$ for private and public sector financing.

From the lending side, loans extended to the private sector curtailed by the slower economic activity that prevailed throughout most of 2012. Thus, the loans extended to the private sector grew in 2012 only by $10.4 \%$ from end 2011 as compared to 2011 and 2010 figure of $12.7 \%$ and $23.1 \%$ (Figure 1).

Moreover, the capitalization rate of Lebanese banks is increased by $17.9 \%$ from December 2011 to reach $12.6 \%$ in December 2012, higher than the Basel II requirements. (Lebanon this week, Byblos Bank, issue 295). In year 2011, the Lebanese banking sector maintained a capital adequacy level of $6.8 \%$ higher than emerging markets, MENA region, regional and worldwide figures (Figure 2).

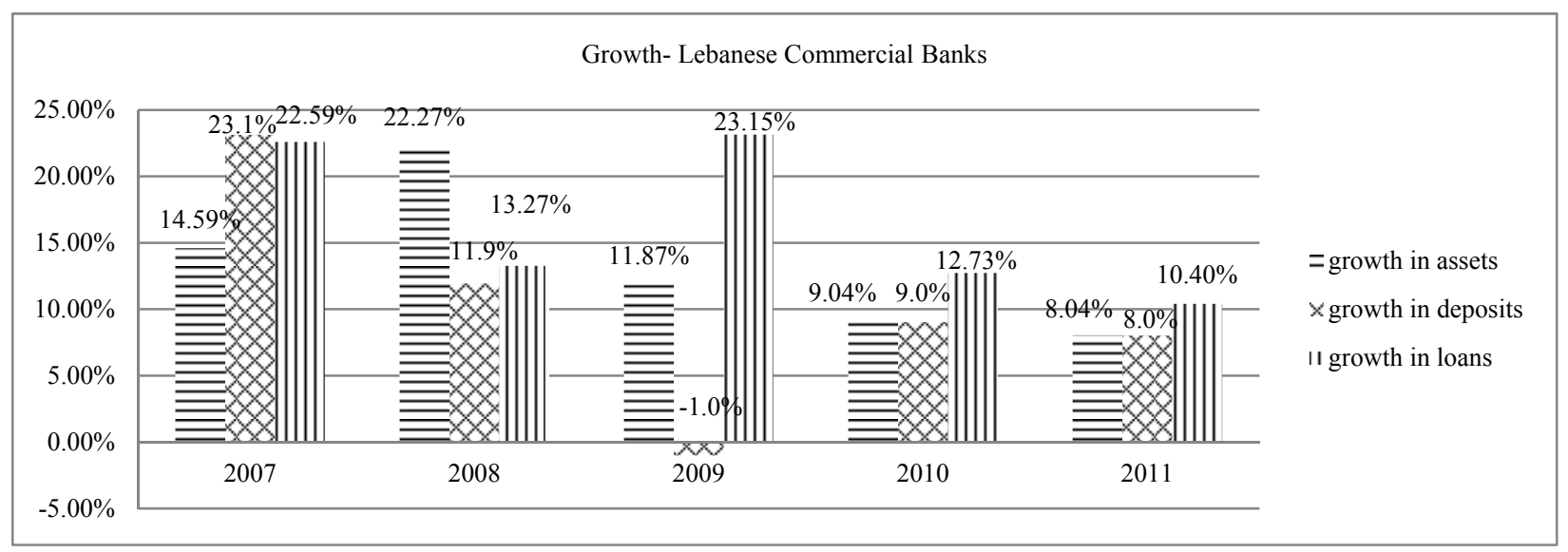

Source: Banque Du Liban (BDL) Data.

Figure 1. Growth of activity indicators 


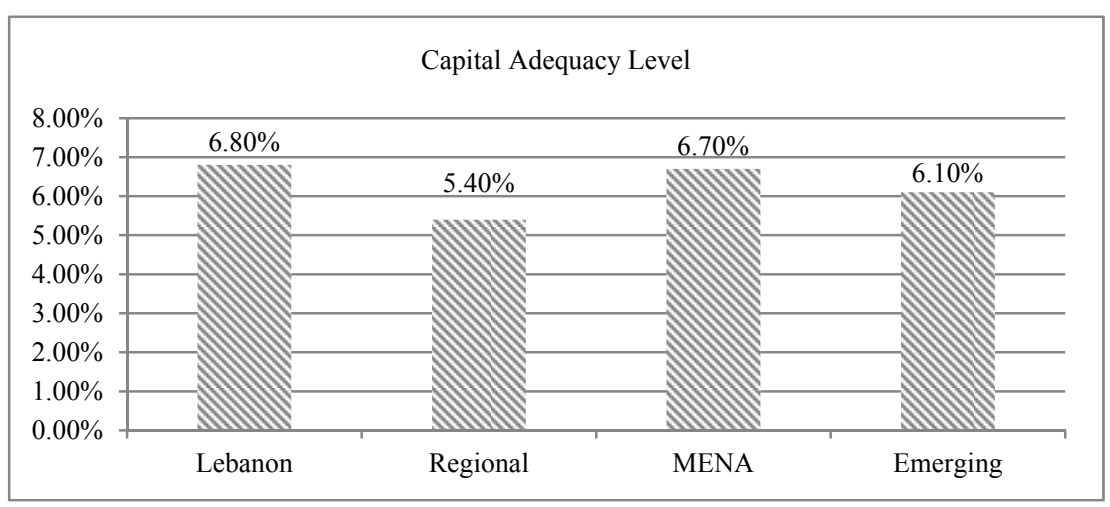

Figure 2. Capital adequacy level-year 2011

Source: BDL Data.

\subsection{Overview of Lebanese Commercial Bank Non-Resident Deposits}

The domestic banks' performance is dependent on the influx of deposits, both resident and non-resident. According to Assaly and Associates (2011), Lebanese banks attracted the largest share in bank deposits in the Middle East in 2010, over 30 percent of total deposits. Mostly, these are flowing from Arabs having high confidence in the Lebanese banking sector and Lebanese immigrants working in the region (Assaly and Associates, 2011).

Lebanese banks are generally characterized by a high deposit profile with $82.4 \%$ of deposits to assets ratio in 2011, being highest among the regional, MENA, emerging markets and world averages (Figure 3).

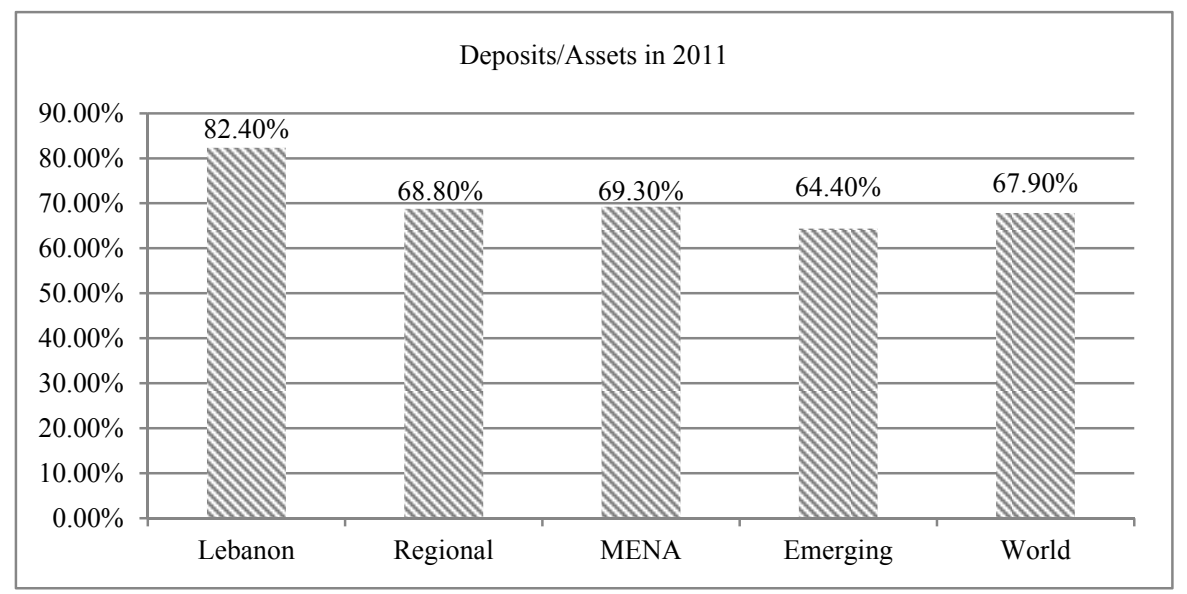

Figure 3. Deposits/assets ratio-year 2011

Source: BDL Data.

Bank deposits can be classified first based on their geographic origin and second based on the currency, so they can be divided into resident and non-resident deposits, and each category is subdivided into local currency deposits (LBP) and foreign currency deposits (FC). FC deposits account for a large part due the high dollarization rates in Lebanon where the US dollar is taking the place in the collection of deposits. Figure 4 shows the deposits dollarization trend from 2000 to 2012. 


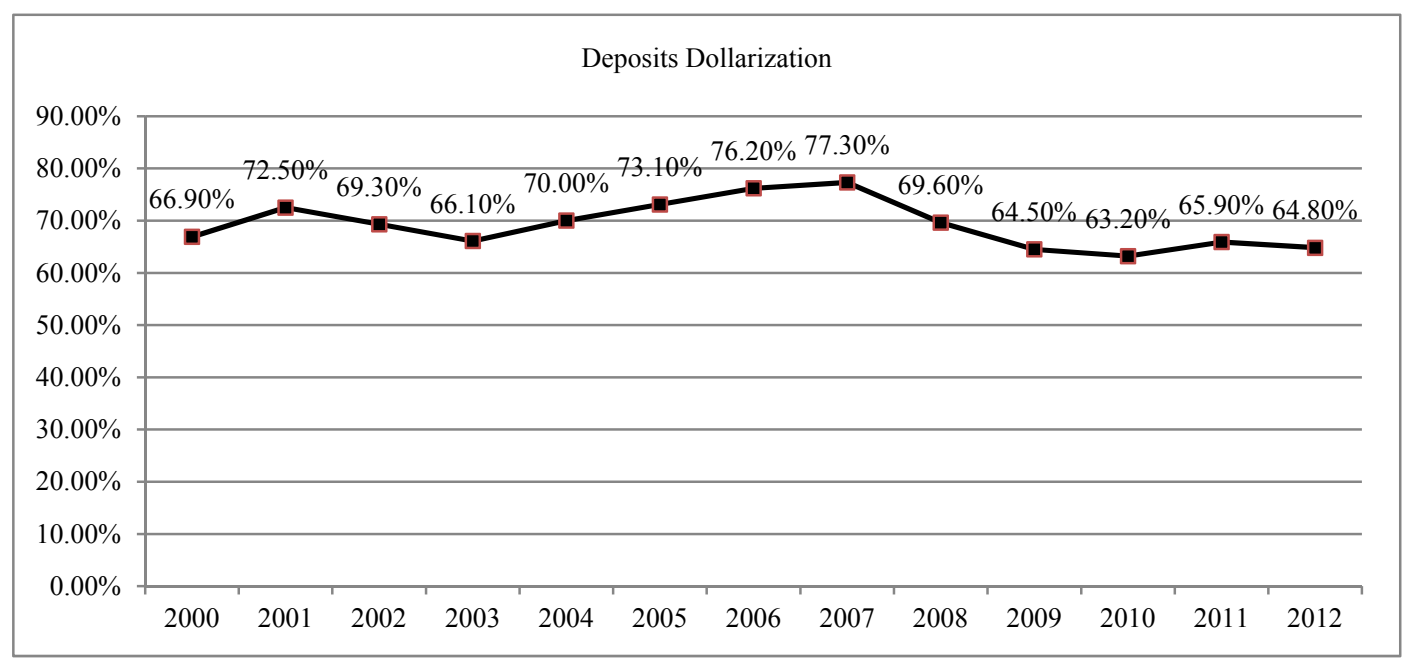

Figure 4. Deposits dollarization 2000-2012

Source: BDL Data.

Non-residents deposits according to articles 1 and 2 of Decree 29 of the Lebanese Law No. 9977, include (i) all deposits hold by all tourists and travelers passing by Lebanon, (ii) by all diplomats of other countries living in Lebanon, (iii) by all companies that are located outside Lebanon, even if they are related to resident persons or companies, and (vi) by all international organizations such as UN, World Bank, and IMF and all embassies (Lebanese Law No.9977, 1977).

Resident and non-resident banking deposits have been on a prolonged rising trend. Historically (from December 1971 till January 2013) the non-resident deposits constituted on average $11.60 \%$ of total deposits with an average annual growth of $2.94 \%$ (Figure 5) which is higher than that of the total deposits of $2.5 \%$. As of January 2013, Non-resident deposits constitute $19.35 \%$ of total deposits. The majority of non-resident deposits are in foreign currency being $86.31 \%$ at the end of 2012 . The foreign currency non-resident deposits (NRFC) represented a quarter of the total foreign currency deposits $(25.79 \%)$ as of January 2013 growing at an average annual rate of $3.05 \%$, as compared to an average annual growth rate of total foreign currency deposits of $2.83 \%$.

The local currency non-resident deposits (NRLC) are also growing at a historical annual average rate greater than that of the total local currency deposits $(2.86 \%$ for NRLC as compared to $2.38 \%$ for total local currency deposits). As of as of January 2013, these deposits are 7.54\% of the total LBP deposits.

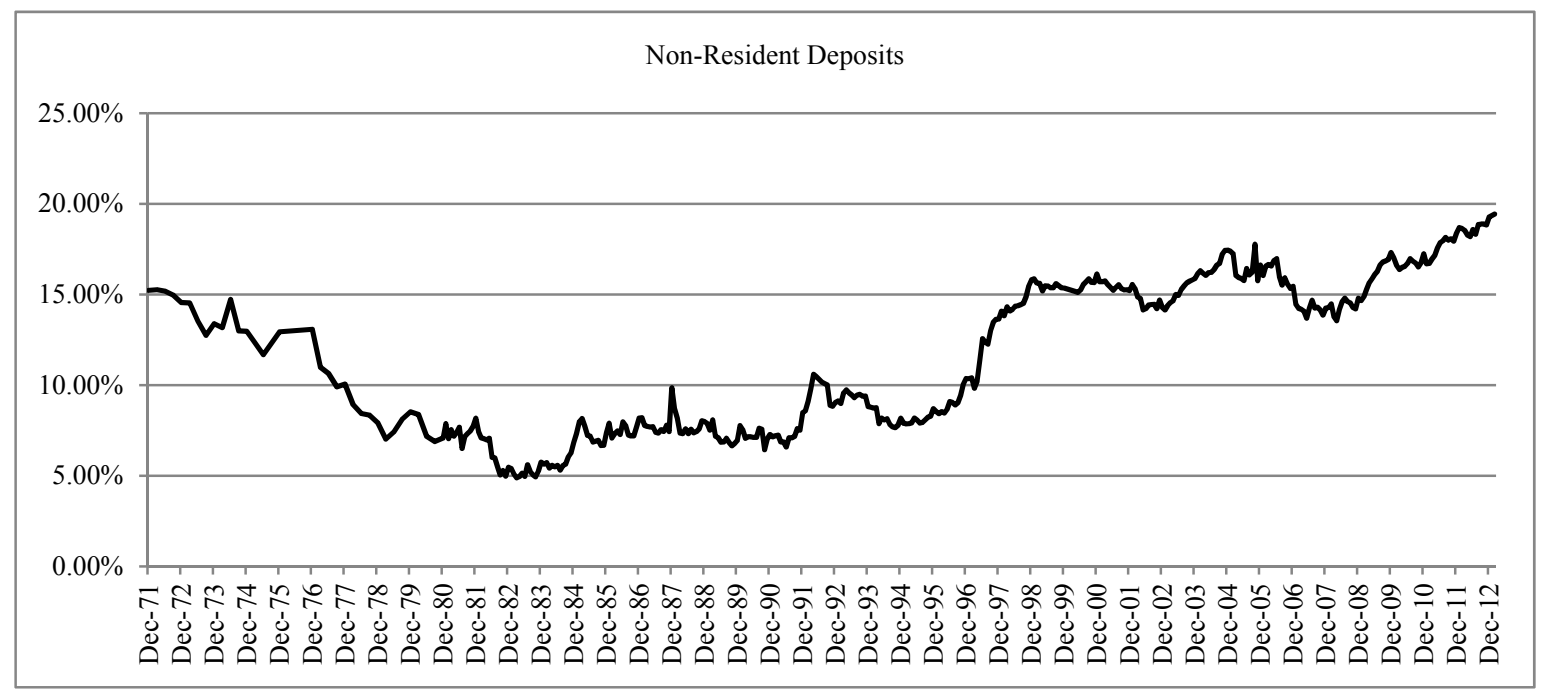

Figure 5. Variation of percentage of NRD of total deposits

Source: BDL Data. 
In conclusion, most of the deposits are in foreign currency and held by residents. However, the positive growth rate of non-resident deposits and the increase in the rates of non-resident foreign currency deposits prove the reliance of the Lebanese bank deposits on those funds flowing from abroad. These deposits are of major importance to the Lebanese banks as source of funds, since non-resident deposits give a hint of the funds flowing from the Lebanese immigrants to their relatives in Lebanon (El Khoury \& Kanj, 2013); such relatives that would also deposit the in-flowing money in the banks and constitute a deposit base.

\section{Literature Review}

There is an extensive literature on saving behavior, both at an individual level and cross- country level. Empirical studies on private savings behavior have categorized a number of potential determinants. Ozcan et al. (2003) outlined six groups of potential saving determinants, namely (i) Demographic determinants (ii) Financial determinants (iii) Income and growth determinants, (iv) external sector determinants (v) uncertainty determinant and (vi) fiscal determinants. Despite the substantial amount of theoretical and empirical work on saving behaviors, little has been done in analyzing the determinants of commercial bank deposits, specifically non-resident deposits.

Non-resident depositors' choice of banks may be affected by different factors than resident deposits. Country risk, economy and banking system soundness may be among additional factors in deciding whether to deposit their money in a specific country and bank. Non-resident deposits' determinants may be similar to those of foreign capital inflows' determinants. Fedderke et al. (2001) examined the determinants of capital flows in South Africa and they found that capital inflows are sensitive to real growth rate of the economy, the interest rate differential, differenced bilateral exchange rates, and political risk. Moreover, Ahmed et al. (2005) examined the capital flows in 81 developing countries between 1975 and 2002, and found that portfolio and equity investment is positively affected by GDP growth rate and negatively affected by the US Treasury bill rate.

Aron et al. (2010) investigated the determinants of non-resident capital flows in South Africa. While annual rates of change of real US GDP, the real US stock market index, improvements in the government surplus to GDP ratio for South Africa, and the change in an index based on the S\&P credit rating positively affect non-resident capital flows, the annual change in the real Johannesburg Stock Exchange JSE index expressed in dollars, the inflation differential relative to the US and for a long-term bond differential with respect to the US, and changes in a US equity market volatility index, VXO, capturing risk aversion negatively affect the capital flows.

Gordon and Gupta (2003) analyzed the determinants of non-resident deposits flows in India and found that they respond positively to the difference between interest rates on these deposits and LIBOR. It is contended that migrants may be more likely to remit into savings account if they can have foreign currency denominated accounts, higher than normal interest rates, tax exemptions, and better exchange rate (Meyers, 1998). Furthermore, Jadhav (2003) found that non-resident deposits are significantly influenced by to interest rate differentials.

Concerning Lebanon, Finger and Hesse (2009) had empirically estimated a number of deposit demand functions, using quarterly data from 1993 to 2008. In their empirical work, they have found that, higher economic activity as measured by the coincident indicator, a higher interest differential, an increase in consumer prices, and a rise in advanced economy industrial production all tend to be associated with stronger deposit growth. Controlling for the external factors GCC, GDP growth or crude oil prices renders the coefficient of the coincident indicator insignificant. Among the variables measuring Lebanon-specific risk or international liquidity and risk aversion, they found a reasonable specification only for the Goldman Sachs Risk Aversion Index. They also attempted to explain bank deposit growth by using a number of bank specific variables; their results suggested that more stable and liquid banks as well as banks with a higher loan exposure are associated with higher deposit growth. In addition, it appeared that a higher net interest margin is also associated with a higher deposit growth. Atrissi (2004) sees that the challenges facing Lebanon in attracting foreign inflows revolve around four angles: Governance, public finance, perception and geopolitical conditions.

Furthermore, an analysis performed in Lebanon by The World Bank in 2012 shows a solid relation between foreign financial inflows and key exogenous and endogenous determinants. They found that oil price (exogenous), accumulation of foreign currency (endogenous), the spread between domestic creditor rates and international interest rates, the lagged dollarization, and the exchange rate regime contribute to the determination of foreign financial inflows to Lebanon (Poverty Reduction and Economic Management Department, 2012).

In summary, Lebanon has been attracting inflows almost throughout all of its history. These inflows are coming from the large Lebanese Diaspora, from neighboring oil exporting countries and investors who are attracted to the real estate and banking sector in Lebanon (El Khoury \& Kanj, 2013). Because Lebanese economy is very 
dependent on the foreign funds inflows, it is important to study most of the possible factors that could affect such deposits. Based on the results, recommendations regarding the economic policies will be developed. Although IMF's research and World Bank's research studied the factors affecting the foreign inflows and deposits in Lebanon from the historical point of view, the main dependent variable was total deposits without separating resident from non-resident deposits. The importance of this study lies in studying the factors affecting non-resident deposits in Lebanon. It will study the effect of internal factors, bank specific factors, and external factors on a monthly basis.

\section{Data}

\subsection{Source of Data}

The data used in this study is secondary monthly data taken from the Banque du Liban (BDL) official website and Political Risk Services (PRS) Group.

Although the data of the dependent variables are available since December 1971, only limited data are available for some of the explanatory variables, therefore, the time frame of the research will be limited to the period from January 2002 till January 2013, to fit the available data, resulting in 131 observations.

\subsection{Variables Specification}

\subsubsection{Dependent Variable}

The dependent variable used in this study is the non-resident deposits measured in three different ways: the non-resident deposits measured as the sum of local currency and foreign currency held by commercial banks in Lebanon (NRD), the non-resident deposits in the local currency (NRLC) and the non-resident deposits in foreign currency (NRFC).

\subsubsection{Independent Variables}

The independent variables that are expected to have an effect on the non-resident deposits are divided into three subgroups: banks specific factors, internal factors (factors related to the economy of the country of the bank), and external factors (factors related to the countries of the non-resident deposits).

\subsubsection{Bank Related Factors}

Bank-related factors may play an important role in explaining the demand for deposits at the bank level (Finger $\&$ Hesse, 2009). Thus, we choose to include:

1) Commercial banks' balance sheet assets (ABNKS) in billions of LBP: This variable would show the size of the commercial banks in Lebanon since the latter is often measured by the total assets (Rose \& Hudgins, 2008). The size would enhance the soundness of the Lebanese commercial banks and increase the confidence in the Lebanese banking sector, thus attract deposits.

2) Number of cards given to non-residents (NRC): It is measured as the total of the non-resident prepaid, debit, credit, and charge cards. This factor is the only available tool for depositors to have access to their money from abroad due to the lack of the application of online banking. According to Mangla (2007), depositors need banking on the go.

3) Dummy Variable (Dbasel): This dummy variable is included to test whether the adoption of the Basel II regulations have affected the confidence of non-resident depositors. Since Basel II regulations lessen the risks of bank and regulate its operations. Basel II was implemented in Lebanon on April 2, 2004 (Banking Control Commission of Lebanon, 2004), this dummy variable will take a value of zero for months prior to April 2004, and one for months starting and including April 2004.

\subsubsection{Internal Factors}

Internal factors are those that are related to the internal Lebanon's conditions such as the economic growth, public debt, war and turmoil inside the country.

1) Coincidence indicator (CI): It is used as a proxy of the current state of the economy. It will replace the GDP since the latter is not available on a monthly basis. The index is computed from a number of data series that move systematically with overall economic conditions and has 1993 as a base year. It is constructed by BDL as an indication of the economic situation. This economic situation was rated as the seventh place in Seshaiah and Narender (2007) study about the criteria for depositors to choose a bank. Furthermore, Finger and Hesse (2009) and Gordon and Gupta (2004) found a positive relation between economic growth and the deposits. 
2) Sovereign debt (SD) in millions of US dollars: This variable poses a sovereign risk on the country and hence deteriorates its economic standing. This is an important factor since the banks in Lebanon are the largest lenders of the government, and any rise in the Lebanese sovereign debt poses a risk on the banks and deposits as well. Thus, deterioration in the sovereign debt condition of Lebanon may pose repayment difficulties on banks specifically for the foreign currency denominated deposits.

3) Interest rates: the weighted average interest rate on deposits in LBP and on deposits in USD is obtained from the official BDL website. The average LIBOR calculated as the average of 1-month, 3-month, 6-month and 12-month LIBOR will be used to compare the difference between the interest rates given by Lebanese commercial banks on deposits and the international arena. The average LIBOR will be used since the dependent variables are a combination of deposits with maturities ranging from 1-month to 12-month. This variable was proven to be an important factor (Finger \& Hesse, 2009; Gordon \& Gupta, 2004) and it will take combinations as follows:

i) $I=i_{L B P}-i_{U S D}$ : It shows the effect of the spread between the rate on LBP ( $\left.i_{L B P}\right)$ and USD ( $\left.i_{U S D}\right)$. This spread is always positive since the interest on LBP deposits through the entire period studied is greater than the interest on USD deposits. The impact of such a variable on NRD deposits depends on whether the deposits are in local or foreign currency. An increase in the interest rates on LBP will increase the spread and the NRLC. On the other hand, an increase in the interest rates on USD will decrease the spread and increase the NRFC. Therefore, a positive relationship is expected between NRLC and I, and a negative relationship is expected between $\mathrm{NRFC}$ and I.

ii) $\mathrm{I}_{1}=\mathrm{i}_{\mathrm{LBP}}$-LIBOR and $\mathrm{I}_{2}=\mathrm{i}_{\text {USD }}-$ LIBOR. These two definitions might show the preference of non-resident depositors for the deposits in Lebanese commercial banks over the international banks that offer near LIBOR interest rates. A positive relationship between this variable and any category of deposits is expected since high interest rates offered by Lebanese commercial banks as compared to the international arena would attract more non-resident deposits. This variable was used by Finger and Hesse (2009).

4) Ratings of International Country Risk Guide (ICRG): This is a rating offered by the Political Risk Services(PRS) Group. Two variables will be used to measure the country risk rating: the political risk rating and the composite risk rating of Lebanon. The political risk rating would show the effect of political turmoil whereas the composite risk rating would show the effect of the overall country rating. The latter might be better than the political rating due to good financial and economic factors which were intact by the political instability. These same ratings were used by Finger and Hesse (2009).

i) The political risk rating (Polrisk):According to ICRG, the calculation of this rating includes government stability, socioeconomic conditions, investment profile, internal conflict, external conflict, corruption, military in politics, religious tensions, law and order, ethnic tensions, democratic accountability, and bureaucracy quality (The PRS Group). Since Lebanon has a lot of political incidents, this might have a large effect on the decision of non-resident depositors to keep their money in the Lebanese banks. Thus, it is expected that this variable has a negative relationship with the non-resident deposits due to the negative picture that the political turmoil will set on the overall country condition and on the confidence in its institutions and economy.

ii) Composite risk (risk): This includes financial, political and economic risk (The PRS Group). Accorinding to PRS Group calculation of composite risk, a higher number of composite risks indicates a lower risk and a better rating. Thus, the overall risk rating for Lebanon will positively affect the investment decision of investors, especially foreign investors.

5) 2006 War (D1): It is a dummy variable that accounts for the second Israeli war in July-September 2006. D1 takes a value of 1 for July, August, and September 2006 and zero elsewhere. D1 will test whether the Lebanese war affected the non-resident deposits.

6) Prime Minister Assassination (D2): it is a dummy variable that takes the value of 1 for the period after the assassination of the Prime Minister Mr. Hariri, from February 2005 till April 2005 when the Syrian troops left Lebanon. Hariri assassination created a huge political instability in the country and lead to lots of demonstrations. D2 will test the effect of such strong, acute and sudden political instability on the non-resident deposits. This dummy is different from the ratings of political risk since the ratings may not capture precisely the effect of one specific event that had created lots of media negative coverage and public opinion. Ratings may not be of large access to non-residents whereas the media coverage of demonstrations and the assassination would reach the entire world through the press. 


\subsubsection{External Factors}

The external factors include factors that are related to the economic situation outside Lebanon such as oil prices and the economic situation of the rest of the world.

1) Oil prices (Oil): The wealth level of non-residents would affect their savings ability and hence affect the non-resident deposits in Lebanon. Since most flows of funds come from GCC countries (Finger \& Hesse, 2009), the oil prices may be a rough representations of the GCC residents' well-being.

2) Financial Crisis (D3): It is a dummy variable that captures the 2008 financial crisis; it is equal to 1 between January 2008 till March 2009 and 0 elsewhere. The financial crisis period was chosen between January 2008 and March 2009, since the most indicative indexes such as S\&P500, DOW, FTSE100 and NASDAQ in U.S markets, CAC40 and DAX in European markets; and Nikkei in Asian markets show a downturn during this period. This downturn had affected lots of non-residents; many jobs were lost and many businesses were bankrupted, thus the income of many non-residents had declined which may significantly affect their deposits in Lebanon.

\section{Methodology}

\subsection{Model Specification}

As concluded from the literature review, the non-residents deposits is determined by three types of factors: (1) factors related to the economy of the country of the banks (internal factors), (2) factors related to the economy of the non-resident deposits (external factors), and (3) bank related factors. Hence the study will investigate the effect of those factors on non-resident deposits through the use of historical secondary data collected from the central bank of Lebanon.

Similarly to previous studies, a linear regression model is used to capture the historical effect of various quantitative factors on banks' deposits. To be able to apply the linear regression, all the variables should be stationary and the residuals should be homoscedastic and not auto correlated. For building this model, the Hendry "general-to-specific" methodology was used. The tests necessary for the empirical study are performed using E-views.

The basic regression framework used in the analysis is as follows:

$$
\begin{aligned}
X_{t}=c+\alpha_{1} \text { ABNKS }_{t}+\alpha_{2} N R C_{t} & +\alpha_{3} \text { Dbasel }_{t}+\alpha_{4} C_{t}+\alpha_{5} S D_{t}+\alpha_{6} I_{t}+\alpha_{7} I I_{t}+\alpha_{8} I 2_{t}+\alpha_{9} \text { risk }_{t}+\alpha_{10} \text { polrisk }_{t} \\
& +\alpha_{11} D 1_{t}+\alpha_{12} D 2_{t}+\alpha_{13} \text { oil }_{t}+\alpha_{14} D 3_{t}+\varepsilon_{t}
\end{aligned}
$$

Where:

$X:$ is one of the three categories of the non-resident deposits: Non-resident foreign currency $\left(N R F C_{t}\right)$; Non-resident local currenc $\left(N R L C_{t}\right)$ y; and Non-resident total deposits $\left(N R D_{t}=N R F C_{t}+N R L C_{t}\right)$;

ABNKS: Bank assets;

$N R C$ : Non-resident cards;

Dbasel: Dummy of the Basel II adoption;

$C I$ : Coincident indicator;

$S D$ : Sovereign debt;

I: Spread between LBP interest rate and USD interest rate;

I1: Spread between the LBP interest rate and the LIBOR;

I2: Spread between the USD interest rate and the LIBOR;

Polrisk: Political risk rating;

Risk: Composite risk rating;

D1: The dummy that measures the effect of 2006 war;

D2: The dummy that measures the effect of Mr. Hariri assassination;

Oil: Oil prices;

D3: The dummy that measures the effect of the 2008 financial crisis;

$t=1,2, \ldots$.

\subsection{Stationarity of Variables}

Nonstationarity can strongly influence the behavior and properties of the series; to test the stationarity of all the 
variables, we use the Augmented Dickey Fuller test (ADF) to reveal if the data has a unit root; where a p-value greater than $5 \%$ indicates that the data has a unit root test and is non-stationary.

Results in table 1 indicate that the null hypothesis of unit root test cannot be rejected except for CI, risk, and oil, implying that only three variables are stationary at level while all other variables are non-stationary. However, the first-difference of the series rejects the hypothesis of a unit root which implies that each data series are integrated in the first order, i.e. I(1). Therefore, the non-stationary variables will be included in the regression as first difference.

If autocorrelation of residuals is present, then it can be removed by adding $X$ lags of $Y_{t}$ in the first difference. Using Ljung-Box test, autocorrelation of residuals exist for all of the variables at the month-on-month first difference. Hence, we include to the model a lag of $X_{t}$.

Table 1. ADF stationarity test results

\begin{tabular}{|c|c|c|}
\hline \multicolumn{3}{|c|}{ Results of unit root test/ Stationarity test } \\
\hline Variables & Level P-value & First Difference P-value \\
\hline NRD & 0.97 & 0.00 \\
\hline NRFC & 0.95 & 0.00 \\
\hline NRLC & 0.97 & 0.00 \\
\hline ABNKS & 0.94 & 0.00 \\
\hline NRC & 0.85 & 0.00 \\
\hline $\mathrm{CI}^{*}$ & 0.03 & 0.00 \\
\hline $\mathrm{SD}$ & 0.11 & 0.00 \\
\hline I & 0.47 & 0.00 \\
\hline I1 & 0.82 & 0.00 \\
\hline $\mathrm{I} 2$ & 0.89 & 0.00 \\
\hline RISK* & 0.01 & 0.00 \\
\hline POLRISK & 0.10 & 0.00 \\
\hline $\mathrm{OIL}^{*}$ & 0.03 & 0.00 \\
\hline
\end{tabular}

*Stationary at level. Computed by authors using E-views 7.

\subsection{Testing for Classical Linear Regression Model (CLRM) Assumptions}

Classical Linear Regression Model (CLRM) assumptions are important to be tested to ensure the accurateness of results in the regression model.

First, to make the mean of the errors equals to zero, a constant will be included in the model. This constant, even if not significant, should be kept in the model, because upon removing the constant, biased slopes may appear, leading to inability to perform the tests of the residuals and all diagnostic tests.

Second, to test homoscedasticity, Goldfeld and Quandt test (1965) will be used, consisting of dividing the entire sample of data into two subsamples, by the period where high fluctuations appear to be. This test is possible only with NRD and NRFC. As for the NRLC, White's test will be used due to the inability to divide the sample into two subsamples. The results of the test are summarized in Table 2. The results conclude that there is homoscedasticity so no further corrections for the sample are required.

Third, in the presence of residuals autocorrelation, statistical inferences can be misleading; therefore, Breusch-Godfrey test as used by Dholakia and Saradhi (2000) is adopted in this study. Because data is monthly, we include 12 lags in the test, allowing a one year autocorrelation in the residuals. The P-value of the test for the three dependent variables is greater than $5 \%$ as shown in Table 3. Therefore, the null hypothesis of no autocorrelation is not rejected, suggesting the presence of no autocorrelation of errors. 
Table 2. Homoscedasticity test results

\begin{tabular}{ccccc}
\hline \multicolumn{5}{c}{ Goldfeld and Quandt test results } \\
\hline Variable & $\begin{array}{c}\text { Period that divides } \\
\text { the subsamples }\end{array}$ & $\mathrm{S}_{1}{ }^{2} / \mathrm{S}_{2}{ }^{2}$ & $\mathrm{~F} 1-\alpha / 2(\mathrm{~T} 1-\mathrm{n} 1-\mathrm{k}, \mathrm{T}-\mathrm{T} 1-\mathrm{n} 2-\mathrm{k})$ & Result \\
NRD & Oct.2005-Nov.2005 & 0.39 & $\mathrm{~F}(13.52) \approx 1.92$ & $0.39<1.92=>$ do not reject H0 \\
NRFC & Oct.2005-Nov.2005 & 0.68 & $\mathrm{~F}(13.52) \approx 1.92$ & $0.68<1.92=>$ do not reject H0 \\
\hline \multicolumn{5}{c}{ White test results } \\
\hline Variable & F-statistic & P-value & \multicolumn{3}{c}{ Result } \\
NRLC & 0.5054 & 0.95 & P-value $=95 \%>5 \%=>$ do not reject H0 \\
\hline
\end{tabular}

Computed by authors using E-views 7 .

Table 3. Breusch-godfray

Computed by authors using E-views 7 .

\begin{tabular}{cc}
\hline \multicolumn{2}{c}{ Breusch-Godfray serial correlation LM test } \\
\hline Variables & P-value \\
NRD & 0.1380 \\
NRFC & 0.0989 \\
NRLC & 0.4150 \\
\hline
\end{tabular}

\subsection{Mutlicollinearity}

To test for multicollinearity, Table 4 shows the matrix of correlations of the variables used in the regressions at first level difference. As observed from the table, multicollinearity is not a serious problem since the majority of the correlation coefficients are not more than 0.8 (Cooper \& Schindler, 2010), thus enhanced the reliability for regression analysis. However, risk and oil have high correlation with $\mathrm{CI}$; which will be solved by either excluding CI from the model or excluding risk and oil from the model. Furthermore, DI1 and DI2 will be tested each at a time in the regression models to avoid multicollinearity. All other variables have low correlation posing no issue for the regression models.

In summary, in the empirical study, the secondary data consists of 131 observations. After testing for stationarity, homoscedasticity, autocorrelation, and multicollinearity, the ordinary least square regression can be safely applied.

Table 4. Correlations of variables at first difference

\begin{tabular}{|c|c|c|c|c|c|c|c|c|c|c|c|c|c|c|c|c|c|c|}
\hline & Tariables & 1 & 2 & 3 & 4 & 5 & 6 & 7 & 8 & 9 & 10 & 11 & 12 & 13 & 14 & 15 & 16 & 17 \\
\hline 1. & GNFC & - & .28 & .98 & .55 & .07 & .02 & .11 & .10 & -.20 & -.13 & -.01 & .03 & .11 & -.18 & -.19 & .04 & .04 \\
\hline 2. & GNRLC & & - & .44 & .34 & -.07 & -.03 & .15 & -.11 & -.10 & -.02 & .06 & .03 & .43 & -.19 & -.33 & .04 & .25 \\
\hline 3. & GNRD & & & - & .58 & .05 & .01 & .13 & .07 & -.21 & -.12 & .00 & .03 & .17 & -.19 & -.24 & .04 & .07 \\
\hline 4. & DABNKS & & & & - & -.06 & .16 & .36 & .00 & -.07 & .03 & .10 & .19 & .15 & -.23 & -.20 & .21 & .10 \\
\hline 5. & DNRC & & & & & - & .00 & .02 & .14 & -.05 & -.06 & -.04 & .06 & -.08 & -.03 & -.06 & .00 & -.18 \\
\hline 6. & DBASEL & & & & & & - & .56 & -.12 & .15 & .10 & .01 & .70 & -.09 & .08 & .08 & .65 & .18 \\
\hline 7. & $\mathrm{CI}$ & & & & & & & - & -.14 & .05 & .08 & .07 & .79 & -.03 & -.22 & -.13 & .76 & .02 \\
\hline 8. & DSD & & & & & & & & - & -.15 & -.16 & -.08 & -.08 & .07 & .03 & -.02 & -.12 & -.09 \\
\hline 9. & DI & & & & & & & & & - & .66 & .05 & .01 & -.38 & -.08 & .43 & .13 & .21 \\
\hline 10. & DI1 & & & & & & & & & & - & .79 & .00 & -.29 & .03 & .22 & .10 & .29 \\
\hline 11. & DI2 & & & & & & & & & & & - & -.01 & -.07 & .11 & -.05 & .02 & .22 \\
\hline 12. & RISK & & & & & & & & & & & & - & .04 & -.07 & -.03 & .71 & -.04 \\
\hline 13. & DPOLRISK & & & & & & & & & & & & & - & .04 & -.32 & -.06 & .05 \\
\hline 14. & D1 & & & & & & & & & & & & & & - & -.02 & .01 & -.05 \\
\hline 15. & D2 & & & & & & & & & & & & & & & - & -.09 & -.05 \\
\hline 16. & OIL & & & & & & & & & & & & & & & & - & .21 \\
\hline 17. & D3 & & & & & & & & & & & & & & & & & - \\
\hline
\end{tabular}

Computed by authors using E-views 7. 


\section{Empirical Findings and Result Discussion}

\subsection{Trends of the NRD}

The total NRD moves very closely to the NRFC, due to the large percentage of NRD being in foreign currencies and not in local currencies. While the non-resident deposits in foreign currencies constitute, on average (Note 1), $90.25 \%$ of non-resident deposits in Lebanon, the non-resident deposits in local currencies are only $9.75 \%$ of the total deposits.

Despite the humble amounts of NRLC as compared to the NRFC, the NRLC deposits grow faster than the NRFC. More specifically, the NRFC and total NRD grow at a monthly average rate of $1.05 \%$ and $1.09 \%$ respectively with a total growth rate of $267.97 \%$ and $289.13 \%$ respectively from January 2002 till January 2013 . On the other hand, NRLC grows at a monthly average rate of $1.57 \%$ and a rate of $508.93 \%$ for the entire period. NRFC deposits as percentage of total deposits is decreasing with time, supporting the previous finding that NRLC deposits are growing at a faster rate as compared to NRFC.

\subsection{Regression Analysis}

After correcting for all CLRM assumptions, different dynamic models with the inclusion of the lagged dependent variables were used to find the determinants of foreign currency deposits.

A dynamic model is created by adding one lag of the dependent variable on the right hand side of the equation; this will account for the reactions of depositors to the changes in the Lebanese commercial banks' size growth, the interest rate spread change, the change in real estate transactions, the war, etc ... which are not instantaneous reactions. Rather, these reactions of depositors are most likely to be distributed over time; this is due to time delays in the transmission and reception of the information regarding the changes in the explanatory variable upon which the depositors base their actions, hence creating a change in the growth of non-resident deposits.

Four econometric specifications are estimated. We start by including only bank specific variables, namely month on month difference in bank assets, number of non-resident cards, and dummy of the Basel II adoption (Model 1). We then add the internal variables in Model 2. Model 3 further add the external variables. Finally, Model 4 reports the regression results after removing all the insignificant variables and the variables that might create the problem of multicollinearity.

\subsubsection{Determinants of Non-resident Foreign Currency Deposits}

Regarding the bank specific variables, Table 5 shows that month on month difference in bank assets positively affect GNRFC and its effect remains significant at $1 \%$ in all models, in line with Finger and Hesse (2009). The result indicates that larger bank might be able to better attract deposits since larger banks are considered to be sounder, which will increase the non-resident depositors confidence in this bank, resulting in more deposits. In all models applied, we find no statistical significance impact of other bank specific variables on GNRFC.

Table 5. Results of regression for GNRFC

\begin{tabular}{|c|c|c|c|c|c|c|c|c|}
\hline & \multicolumn{2}{|c|}{ Model 1} & \multicolumn{2}{|c|}{ Model 2} & \multicolumn{2}{|c|}{ Model 3} & \multicolumn{2}{|c|}{ Model 4} \\
\hline & Coeff & P-value & Coeff & P-value & Coeff & P-value & Coeff & P-value \\
\hline $\mathrm{C}$ & -0.002348 & 0.9968 & 5.923005 & 0.4228 & 5.229341 & 0.5112 & -0.170653 & 0.6848 \\
\hline $\mathrm{D}(\mathrm{ABNKS})$ & 0.001492 & $0.0000^{* * *}$ & 0.001395 & $0.0000^{* * *}$ & 0.001396 & $0.0000^{* * *}$ & 0.001308 & $0.0000^{* * *}$ \\
\hline $\mathrm{D}(\mathrm{NRC})$ & 0.000138 & 0.1568 & 0.000009 & 0.4003 & 0.000009 & 0.3742 & & \\
\hline DBASEL & -0.684666 & 0.2367 & 0.418575 & 0.6011 & 0.198872 & 0.8157 & & \\
\hline CI & & & -0.004972 & 0.6199 & -0.00682 & 0.5599 & & \\
\hline $\mathrm{D}(\mathrm{SD})$ & & & 0.00043 & 0.4186 & 0.000427 & 0.4239 & & \\
\hline $\mathrm{D}(\mathrm{I})$ & & & -3.172700 & $0.0103^{* *}$ & -3.46336 & $0.0087^{* * *}$ & -3.121528 & $0.002^{* * *}$ \\
\hline $\mathrm{D}(\mathrm{I} 2)$ & & & -0.687926 & 0.4236 & -0.79069 & 0.3633 & & \\
\hline D(POLRISK) & & & -0.26113 & 0.4033 & -0.28691 & 0.3666 & & \\
\hline RISK & & & -0.097116 & 0.5232 & -0.08195 & 0.6071 & & \\
\hline D1 & & & -3.427727 & $0.044^{* *}$ & -3.45859 & $0.0597^{*}$ & -3.069178 & $0.0293^{* *}$ \\
\hline D2 & & & -2.215031 & $0.0412^{* *}$ & -1.99779 & $0.0846^{*}$ & -1.720909 & $0.0456^{* *}$ \\
\hline
\end{tabular}




\begin{tabular}{|c|c|c|c|c|c|c|c|c|}
\hline Oil & & & & & 0.004249 & 0.7104 & & \\
\hline D3 & & & & & 0.425479 & 0.4418 & & \\
\hline GNRFC(-1) & -0.248463 & $0.0654^{*}$ & -0.299321 & $0.0383^{* *}$ & -0.30037 & $0.038^{* *}$ & -0.305352 & $0.0354^{* *}$ \\
\hline Adjusted $\mathrm{R}^{2}$ & $35.78 \%$ & & $38.03 \%$ & & $37.22 \%$ & & $39.31 \%$ & \\
\hline $\mathrm{R}^{2}$ & $37.76 \%$ & & $43.75 \%$ & & $43.97 \%$ & & $41.64 \%$ & \\
\hline $\mathrm{N}$ & 131 & & 131 & & 131 & & 131 & \\
\hline
\end{tabular}

Computed by authors using E-views $7 .{ }^{* * *}$ significant at $1 \%$; **significant at $5 \%$; *significant at $10 \%$.

As shown in Table 5, the regression shows higher explanatory power when internal variables are added to the estimation; the adjusted R-square improves from $37.76 \%$ to $43.75 \%$, indicating that these variables are explaining part of NRFC. More specifically, there is evidence that Dummy 1 and Dummy 2 have a significant negative relationship as expected irrespective of the model applied, suggesting that the war and the assassination of the prime minister adversely affect the flow of foreign currency deposits in the Lebanese commercial banks. There is also evidence, although not robust in the model, indicating that the change in the spread between the LBP and USD interest rate affects the growth of non-resident deposits in foreign currency. Although this variable is significant in Model 2 only at $5 \%$, it is significant at $1 \%$ in Model 3 when external variables are added, suggesting that depositors might be positively influenced by high interest rates.

However, when external variables are added to the regression in Model 3, the adjusted R-square slightly declines indicating that these variables do not affect the growth of non-resident foreign currency depositors. This is supported by the insignificance coefficient of all external variables.

The magnitude and significance of the coefficient on the lagged GNRFC confirm the dynamic nature of the model.

The final empirical model for the growth of NRFC would be:

$$
G N R F C_{t}=c+\alpha_{1} D A B N K S G_{t}+\alpha_{6} D(I)_{t}+\alpha_{11} D 1_{t}+\alpha_{12} D 2_{t}+\alpha_{15} G N R F C(-1)_{t}+\varepsilon_{t}
$$

Where: GNRFC is the month-on-month growth of non-resident foreign currency deposits;

$A B N K S G$ is the month-on-month difference in bank assets;

$D(I)$ is the first difference of the difference between USD and LBP interest rates;

$D 1$ is the dummy variable that measures the effect of 2006 war;

$D 2$ ishe dummy that measures the effect of Mr. Hariri assassination;

GNRFC(-1) is the lag of GNRFC.

\subsubsection{Determinants of Non-Resident Local Currency Deposits}

Similar to the NRFC, Table 6 shows that bank asset size has a significant positive impact in all models. Furthermore, the regression shows the highest explanatory power when internal and external variables are added to the regression.

While Dummy 1 is not significant, Dummy 2 has a significant negative relationship irrespective of the model applied, suggesting that the assassination of the prime minister and not the war adversely affect the flow of foreign currency deposits in the Lebanese commercial banks. Furthermore, the positive and significant coefficient of political risk suggests that a higher political score, indicating low level of risk, will attract non-resident depositors to deposit more money in the local currency. Thus, a higher score will increase the safety of deposits and will increase the confidence in the banking sector in Lebanon. Furthermore, $\mathrm{I}_{1}$ has a positive and significant coefficient, suggesting that higher interest rates offered by Lebanese commercial banks as compared to the international arena would attract more non-resident deposits. 
Table 6. Results of regression for G (NRLC)

\begin{tabular}{|c|c|c|c|c|c|c|c|c|}
\hline & \multicolumn{2}{|c|}{ Model 1} & \multicolumn{2}{|c|}{ Model 2} & \multicolumn{2}{|c|}{ Model 3} & \multicolumn{2}{|c|}{ Model 4} \\
\hline & Coeff & P-value & Coeff & P-value & Coeff & P-value & Coeff & P-value \\
\hline $\mathrm{C}$ & 0.549343 & 0.5685 & 25.51516 & 0.2471 & 10.77216 & 0.6134 & 0.021111 & 0.9736 \\
\hline D(ABNKS) & 0.001454 & $0.002^{* * *}$ & 0.000918 & $0.0146^{* *}$ & 0.000903 & $0.0084^{* * *}$ & 0.001135 & $0.0148^{* *}$ \\
\hline $\mathrm{D}(\mathrm{NRC})$ & -0.000158 & 0.3121 & -0.000005 & 0.8235 & 0.000003 & 0.8469 & & \\
\hline DBASEL & -1.127992 & 0.3528 & -0.01021 & 0.9951 & -0.58977 & 0.7482 & & \\
\hline CI & & & 0.026111 & 0.2803 & 0.04448 & $0.0937^{*}$ & & \\
\hline $\mathrm{D}(\mathrm{SD})$ & & & -0.00151 & 0.3532 & -0.00156 & 0.3076 & & \\
\hline $\mathrm{D}(\mathrm{I})$ & & & 3.811279 & 0.4983 & 3.980446 & 0.4998 & & \\
\hline $\mathrm{D}(\mathrm{I} 1)$ & & & 0.85195 & 0.5643 & -0.54254 & 0.744 & & \\
\hline D(POLRISK) & & & 3.158281 & $0.0042^{* * *}$ & 2.965584 & $0.0073^{* * *}$ & 2.646063 & $0.0066^{* * *}$ \\
\hline RISK & & & -0.51142 & 0.2676 & -0.27311 & 0.5325 & & \\
\hline D1 & & & -2.32129 & 0.3246 & -0.74247 & 0.7644 & & \\
\hline $\mathrm{D} 2$ & & & -7.72444 & $0.0551^{*}$ & -7.71014 & $0.0534^{*}$ & -6.71692 & $0.0697^{*}$ \\
\hline Oil & & & 0.065284 & 0.6158 & -0.04012 & 0.1583 & & \\
\hline D3 & & & 25.51516 & 0.2471 & 4.166032 & $0.0151^{* *}$ & 3.893509 & $0.0002^{* * *}$ \\
\hline GNRLC(-1) & 0.176189 & $0.0843^{*}$ & 0.000918 & $0.0146^{* *}$ & 0.010592 & 0.9356 & & \\
\hline Adjusted $\mathrm{R}^{2}$ & $12.97 \%$ & & $28.62 \%$ & & $31.12 \%$ & & $31.06 \%$ & \\
\hline $\mathrm{R}^{2}$ & $15.65 \%$ & & $35.21 \%$ & & $38.54 \%$ & & $33.69 \%$ & \\
\hline $\mathrm{N}$ & 131 & & 131 & & 131 & & 132 & \\
\hline
\end{tabular}

Computed by authors using E-views $7 . * * *$ significant at $1 \%$; ** significant at $5 \%$; *significant at $1 \%$.

Regarding the external variables, contrary to the results of NRFC, there is evidence that D3 has a positive and significant impact, indicating that the financial crisis has positively impacted non-resident deposits in local currency. This result suggests that Lebanese banking sector was considered as immune from the financial crisis, and Lebanese currency was considered as a safe place to deposit money. However, the dynamic nature is inconclusive since the coefficient of the lagged GNRLC is only significant in Model 1.

The final empirical model for the growth of NRFC would be:

$$
\text { GNRFC }_{t}=c+\alpha_{1} \text { DABNKSG }_{t}+\alpha_{10} \text { Polrisk }+\alpha_{12} D 2_{t}+\alpha_{14} D 3_{t}+\varepsilon_{t}
$$

\subsubsection{Determinants of Non-Resident Total Deposits}

As mentioned earlier, NRFC deposits constitute on average of $86.32 \%$ of total non-resident deposits for the studied period, thus it is expected that the variables that are significant for NRFC would also be significant for total NRD. The results in Table 7 support this expectation; all the factors that are significant for NRFC are also significant for NRD.

The final empirical model for the growth of NRD would be:

$$
G N R D_{t}=c+\alpha_{1} A B N K S G_{t}++\alpha_{6} D(I)_{t}+\alpha_{11} D 1_{t}+\alpha_{12} D 2_{t}+\alpha_{16} G N R D(-1)_{t}+\varepsilon_{t}
$$

Where: GNRD is is the month-on-month growth of non-resident deposits;

$A B N K S G$ is the month-on-month growth of bank assets;

$D 1$ is the dummy variable that measures the effect of 2006 war;

$D 2$ The dummy that measures the effect of Mr. Hariri assassination;

$G N R D(-1)$ is the lag of GNRD.

\subsection{Discussion of Findings}

The largest portion of the non-resident deposits in Lebanon is in foreign currency. Thus, all the factors have their effect on the general non-resident deposits are also affecting the foreign currency deposits which are very representative of the total non-resident deposits.

The first question was concerned with uncovering the internal factors that might affect the non-resident deposits. The empirical study showed the war and the assassination of prime minister negatively affect both the non-resident foreign currency deposits and the total non-resident deposits, whereas the composite risk rating and the political risk rating did not prove to be significant factors for those deposits. Non-resident depositors might 
not be informed of the ratings but are informed of war and assassinations occurring in Lebanon, since these events are covered by the public media that reaches all the depositors through various means of information; whereas the ratings are usually of interest to specific category of people who intentionally monitor such factors. While internal factors affecting non-resident deposits are the same for foreign currency and for total deposits, they are different for local currency. More specifically, political risk and assassination of prime minister (political turmoil) negatively affect the non-resident local currency deposits.

Table 7. Results of regression for GNRD

\begin{tabular}{|c|c|c|c|c|c|c|c|c|}
\hline & \multicolumn{2}{|c|}{ Model 1} & \multicolumn{2}{|c|}{ Model 2} & \multicolumn{2}{|c|}{ Model 3} & \multicolumn{2}{|c|}{ Model 4} \\
\hline & Coeff & $\mathrm{P}$-value & Coeff & P-value & Coeff & P-value & Coeff & P-value \\
\hline $\mathrm{C}$ & 0.017085 & 0.9761 & 6.06428 & 0.3762 & 3.910718 & 0.6019 & -0.04139 & 0.9227 \\
\hline $\mathrm{D}(\mathrm{ABNKS})$ & 0.00154 & $0.0000^{* * *}$ & 0.001401 & $0.0000^{* * *}$ & 0.001396 & $0.0000^{* * *}$ & 0.001335 & $0.0000^{* * *}$ \\
\hline $\mathrm{D}(\mathrm{NRC})$ & 0.000118 & 0.1838 & 0.000001 & 0.3928 & 0.000001 & 0.3269 & & \\
\hline DBASEL & -0.766714 & 0.1808 & 0.288258 & 0.7222 & 0.085784 & 0.9204 & & \\
\hline CI & & & -0.003511 & 0.6936 & -0.00256 & 0.8205 & & \\
\hline $\mathrm{D}(\mathrm{SD})$ & & & 0.000161 & 0.7577 & 0.000162 & 0.7557 & & \\
\hline $\mathrm{D}(\mathrm{I})$ & & & -2.122463 & 0.2238 & -2.89715 & $0.0543^{*}$ & -2.81434 & $0.0264^{* *}$ \\
\hline $\mathrm{D}(\mathrm{I} 2)$ & & & -0.468817 & 0.5645 & -0.70254 & 0.4111 & & \\
\hline D(POLRISK) & & & 0.019976 & 0.955 & -0.01788 & 0.961 & & \\
\hline RISK & & & -0.101163 & 0.4699 & -0.06395 & 0.6694 & & \\
\hline D1 & & & -3.273127 & $0.0516^{*}$ & -3.07624 & $0.087^{*}$ & -3.1932 & $0.0241^{* *}$ \\
\hline $\mathrm{D} 2$ & & & -3.113055 & $0.0122^{* *}$ & -2.90427 & $0.0249^{* *}$ & -3.00285 & $0.0032^{* * *}$ \\
\hline Oil & & & & & -0.00198 & 0.8633 & & \\
\hline D3 & & & & & 0.750978 & 0.1402 & & \\
\hline $\operatorname{GNRD}(-1)$ & -0.202411 & 0.132 & -0.272826 & 0.0602 & -0.27548 & $0.0562^{*}$ & -0.2805 & $0.0532^{*}$ \\
\hline Adjusted $\mathrm{R}^{2}$ & $36.45 \%$ & & $39.14 \%$ & & $38.53 \%$ & & $41.34 \%$ & \\
\hline $\mathrm{R}^{2}$ & $38.40 \%$ & & $44.75 \%$ & & $45.15 \%$ & & $43.60 \%$ & \\
\hline $\mathrm{N}$ & 131 & & 131 & & 131 & & 131 & \\
\hline
\end{tabular}

There is no supporting evidence that the state of Lebanese economy as measured by CI has an effect on any of the non-resident deposits. As for the interest rate differential, it has a negative significant effect on the non-resident foreign currency deposits and on the total non-resident deposits; thus, as the interest rate on the USD deposits increases, the spread (I) decreases, and deposits in foreign currency increase. However, this interest rate differential did not prove to have a significant effect on the non-resident local currency deposits. The interest rate differential between Lebanese banks' interest rates on LBP and LIBOR prove to be significant factors on only non-resident local currency deposits.

Concerning the external factors, the empirical study shows no significant external factors that might have an effect on the growth of non-resident deposits in foreign currency and in total deposits. However, the financial crisis in 2006 positively affects non-resident deposits in local currency. This conclusion supports El Khoury and Kanj (2013) findings that non-resident depositors are not affected by factors outside Lebanon and their deposits might even increase in Lebanese banks when the situation in the world deteriorates due to their trust in the Lebanese banking system.

For bank-related factors, the growth of bank size as measured by assets appeared to be a significant factor that affects the growth of non-resident deposits regardless of what it is measured.

\section{Summary and Concluding Remarks}

The purpose of this study was to determine the factors that affect the non-resident deposits in Lebanese banks by using 131 secondary monthly data (from January 2002 till January 2013). This study used an empirical model to research the effect of internal, external, and bank related factors on non-resident deposits. The majority of the deposits are in foreign currency which was previously mentioned by many other literatures like Peters et al. (2004).

As for the internal factors, the economic activity in Lebanon was not proved to be significant whereas this factor was significant in Finger and Hesse (2009) results. The interest rate appeared to be significant for foreign 
currency and total non-resident deposits, similar to Finger and Hesse (2009). The higher interest rate offered on domestic currency as compared to LIBOR appeared to increase the non-resident deposits in local currency. As for the war and the assassination of prime minister, they appear to be significant, whereas the risk ratings and political situation did not have any significant result, as indicated by Finger and Hesse (2009). However, the political situation affected the local currency deposits because the political turmoil might shake the confidence of non-residents in the domestic currency.

Similar to the results of other studies, the external factors were not justified to be significant, except the financial crisis which positively affected non-resident deposits in local currencies. Whereas the bank size as measured by bank assets appeared to be significant, other variables such as cards given to non-residents and adoption of Basel II did not appear to significantly affect non-resident deposits.

The study concludes that some factors can be controlled either by banks or by the government to attract more of the non-resident deposits. For example, the growth of banks assets can be managed by the banking sectors to attract more deposits of non-residents. Furthermore, the government should try to maintain healthy rate differentials to support the deposit growth.

Since the non-resident deposits are negatively affected by war and adverse events such as the assassination of prime minister, Lebanese banks should diversify into international branches. This would reduce the adverse effect of any turmoil happening inside Lebanon on non-resident depositors and would also attract more non-residents for the convenience of banking with the Lebanese international branches as found by El-Khoury and Kanj (2013).

The limitations of the empirical study were the limited data for some variables available on a monthly basis. Some factors that might affect the deposits are not abundant as monthly data, and some others are for a very short period of time that is not enough to conduct an empirical study.

\section{References}

Ahmed, F., Arezki, R., \& Funke, N. (2005). The composition of capital flows: Is South Africa different? IMF Working Paper WP/05/40.

Aron, J., Leape, J., \& Tomas, L. (2010). Portfolio flows; Exchange rate policy and capital markets in South Africa. CSAE Conference: Economic Development in Africa.

Assaly, \& Associates. (2011). Lebanese banks attract largest share of Middle East Deposits. Retrieved from http://www.assalygroup.com/reports/55-lebanese-banks-attract-largest-share-of-middle-east-deposits

Atrissi, N. (2004). Investment challenges in Lebanon-mobilizing investment for development in the MENA region. OECD-hosted Exploratory Senior-level Meeting, Istanbul.

Banking Control Commission of Lebanon. (2004, April). Basel II/general preparations. Banking Control Commission of Lebanon. Retrieved March 7, 2012, from http://www.bccl.gov.lb

Byblos Bank SAL. (2013, February 4-8). Lebanon this week. Retrieved March 08, 2013, from http://www.byblosbank.com.lb/Library/Files/Lebanon/Publications/Economic\%20Research/Lebanon\%20T his\%20Week/Lebanon\%20This\%20Week_295.pdf

Cooper, D. C., \& Schindler, P. S. (2010). Business research methods (11th ed.). Boston: McGraw-Hill.

Dholakia, R. H., \& Saradhi, V. R. (2000). Exchange rate pass-through and volatility: Impact on Indian trade. Economic and Political Weekly, 35(43-53), 4109-4116.

Dibeh, G. (2005). The political economy of postwar reconstruction in Lebanon. EIDER Research Paper Series No. 2005/44.

El-Khoury, R., \& Kanj, O. (2013). Determinants of deposits in Lebanese commercial banks-evidence from non-resident depositors. Journal of Money, Investment and Banking, 27, 151-168.

Eltony, M. N. (2003). Quantitative measures of financial sector reform in the Arab countries. Arab Planning Institute, Kuwait.

Fedderke, J. W., De Kadt, R. H., \& Luiz, J. M. (2001). Indicators of political liberty, property rights and political instability in South Africa: 1935-97. International Review of Law and Economics, 103-134. http://dx.doi.org/10.1016/S0144-8188(00)00051-X

Finger, H., \& Hesse, H. (2009). Lebanon-determinants of commercial bank deposits in a regional financial center. IMF working paper WP/09/195. 
Goldfeld, S. M., \& Quandt, R. E. (1965). Some tests for homoscedasticity. Journal of the American Statistical Association, 60(310), 539-547. http://dx.doi.org/10.1080/01621459.1965.10480811

Gordon, J. P., \& Gupta, P. (2003). Portfolio flows into India: Do domestic fundamentals matter? IMF working paper, WP/03/20.

Hakim, S., \& Neaime, S. (2001). Performance and credit risk in Banking: A comparative study for Egypt and Lebanon. Economic Research Forum, Cairo.

Jadhav, N. (2003). Maximising developmental benefits of migrant remittances: The Indian experience. Paper presented at the International Conference on Migrant Remittances, Department for International Development and World Bank, London.

Lebanese Law No.9977. (1977). Laws relating to banking and financial sector. Retrieved from http://www.bdl.gov.lb/circ/lawpdf/Decree29.pdf

Mangla, I. S. (2009, December 7). 5 reasons banks don't get it. Retrieved from http://money.cnn.com/2009/11/24/pf/bank_services.moneymag/

Meyers, D. W. (1998). Migrant remittances to Latin America: Reviewing the literature. Working Paper, Inter-American Dialogue, The Tomas Rivera Policy Institute.

Naïmy, V. (2004). A proposed restricting of Lebanese public debt to promote economic growth. International Business \& Economics Research Journal, 3(8), 15-26.

Ozcan, K., Asli, G. M., \& Ertac, S. (2003). Determinants of private savings behaviour in Turkey. Applied Economics, 35(12), 1405-1416. http://dx.doi.org/10.1080/0003684032000100373

Poverty Reduction and Economic Management Department. (2012). Using Lebanon's large capital inflows to foster sustainable long-term growth. World Bank, Middle East and North Africa.

Rose, P., \& Hudgins, S. (2008). Bank management and financial services. Boston: McGraw Hill.

Seshaiah, S. V., \& Narender, V. (2007). Factors affecting customers' choice of retail banking. The IUP Journal of Bank Management, VI(1), 34-46.

Note

Note 1. The average for the period studied: January 2002 till January 2013.

\section{Copyrights}

Copyright for this article is retained by the author(s), with first publication rights granted to the journal.

This is an open-access article distributed under the terms and conditions of the Creative Commons Attribution license (http://creativecommons.org/licenses/by/3.0/). 